\title{
ASSESSMENT OF TOURISTS' PERCEPTIONS ON SAFETY AT THE CAPE COAST TOURIST DESTINATION IN GHANA
}

\author{
Nicholas IMBEAH \\ Enyedi Gyorgy Doctoral School for Regional Sciences, Szent Istvan Egyetem, 2100, \\ Godollo, Pater Karoly, u.1. Hungary, e-mail: nicholas.imbeah2012@gmail.com
}

\author{
Aniko KHADEMI-VIDRA \\ Szent Istvan Egyetem, 2100, Godollo, Pater Karoly, u.1. Hungary, \\ e-mail: khademi.vidra.aniko@gtk.szie.hu \\ Zoltan BUJDOSO* \\ Eszterhazy Karoly University Gyöngyös, Hungary, \\ e-mail: bujdoso.zoltan@uni-eszterhazy.hu
}

\begin{abstract}
Citation: Imbeah, N., Khademi-Vidra, A. \& Bujdoso Z. (2020). ASSESSMENT OF TOURISTS' PERCEPTIONS ON SAFETY AT THE CAPE COAST TOURIST DESTINATION IN GHANA. GeoJournal of Tourism and Geosites, 28(1), 217-231. https://doi.org/10.30892/gtg.28117-464
\end{abstract}

\begin{abstract}
The study aimed at identifying the precautionary measures taken by tourists before traveling and measures adopted while at the destination. Purposive sampling technique and questionnaires were employed to survey 515 tourists. It became evident that as the level of the tourists' safety satisfaction increased, their safety expectations also increased. Tourists' purpose of visiting did not influence the perception of safety. Majority of the tourists had at least a high school education. Therefore, their impressions could be critical for stakeholders to consider them in tourism safety planning. It recommended that GTA should add installation and repairs of safety equipment in unannounced routine checks. It is expected that this study will lead to further research on tourist safety and security within Ghana and her neighbouring countries in West Africa to reflect the regional position on tourism safety.
\end{abstract}

Key words: tourist safety, expectations, satisfaction, Ghana, destination

\section{INTRODUCTION}

\section{Background of the study}

The personal safety of tourists at the destination is relevant to tourists and destination managers, and therefore the perceived and actual risk associated with travel and tourism has made safety and security very critical in the promotion of tourism (Mopeli, 2009). The subject of safety and security has become more imperative not only

\footnotetext{
* Corresponding author
} 
for the host-community but also for the tourist who is a guest (Cavlek, 2002, Bujdosó et al., 2011, 2015, Bujdosó-Dávid, 2013, Mátyás and Csege, 2019) in a new environment.

As Mansfeld and Pizam (2006) opined, peace, safety and security are the three prerequisites for thriving tourism development in every destination. Many types of research have been conducted across the world on safety and security of tourists, namely: Lisowska, (2017), Mansfeld and Pizam (2006), Cavlek (2002), Breda and Costa (2006), Reisinger and Mavondo (2005), Ferreira and Harmse, (2000), George, (2003). As usual, these and many other studies concentrated on evaluating the natural destination safety elements, namely, health, terrorism, natural disasters, crime and political instability (Bujdosó, 2009). Admittedly, authors have written on issues of tourism safety and security from a wide range of perspectives, but the perceptions of tourists in Cape Coast tourist destination in Ghana have not been widely explored, and subsequently, this paper seeks to add to the discussion on the personal measures tourists take before travelling. The aims of this paper are to: identify the safety and security facilities at the destination; ascertain tourists' purpose of travelling and examine the precautionary measures taken by tourists before travelling and measures adopted while at the destination. The paper chose Cape Coast Castle, Elmina Castle and Kakum National Park (KNP) in the Central Region of Ghana for the study.

\section{Contribution to the tourism sector in Ghana}

The tourism sector in Ghana has remained a steady contributor to economic growth and development. According to the Institute of Statistical, Social and Economic Research (ISSER) (2017), tourism has been a significant source of foreign exchange, employment and government revenue in Ghana. In the report of World Travel and Tourism Council (WTTC), in 2016, travel and tourism generated a total of US\$ 7.6 trillion (10.2\% of global GDP) and 292 million jobs, equal to 1 in 10 jobs in the worldwide economy. The contribution of the tourism sector in 2016 to total employment, both direct and indirect was 5.9\%, representing 693,00o jobs.

In the assessment of ISSER (2017), tourism arrivals were estimated at 1,322,500 in 2016, representing a 10\% increase from 2015. Revenue from tourism also went up by nearly $10 \%$ from US \$ 2, 275.2 million in 2015 to US\$ 2, 505.5 million in 2016. Tourism is now either the 3 rd or 4th foreign exchange earner in Ghana and its contribution to GDP was around 5.8 in 2017 (Ghana Tourism Authority, GTA, 2017).

\section{Safety in the West African Region}

The apparent compelling force for discussion on this subject is the fact that the activities of terrorists might tarnish the right image of tourist destinations in Africa as a whole and West Africa in particular. For example, on 13th March 2016, Al Qaeda alJihad in the Islamic Maghreb (AQIM) attacked a beach resort near Abidjan in Ivory Coast, a neighbouring country of Ghana. Armed men carried out the attack on L'Etoile du Sud hotel and hotel Nouvelle Paillote at Grand Bassam's tourist resort, killing 16 civilians and three soldiers and injuring 24 others (Gunaratna, 2016).

Also, on 9th January 2016, the BBC carried the news item that three tourists were stabbed at Hurghada Hotel in Egypt. These foreign tourists were stabbed by two suspected Islamic State militants who stormed into a hotel in Egypt's Red Sea resort of Hurghada (BBC News, 2016). On the 11th December, 2016 a suicide bombing occurred at the Coptic cathedral in Egypt where 26 people were killed and 45 others injured (African Research Bulletin, 2017). Besides, in 2016 militants of Al-Qaeda in the Islamic Maghreb (AQIM) attacked a hotel and killed 29 people in Burkina Faso also Ghana's neighbouring country. The attack happened at the Splendid Hotel and a nearby Cappuccino café in Ouagadougou (BBC News, 2016). In the recent report from OSAC (2019), over eleven destinations in Burkina Faso have been declared as unsafe places to 
visit for recreational and tourism activities. In this report, the U.S. Department of State Travel Advisory indicated that travellers should reconsider travel to the country due to terrorism, crime and kidnapping. There is a considerable risk from crime in Ouagadougou, the capital city of Burkina Faso. The surge of these attacks on tourist destinations in West Africa has made research into this topic imperative.

Though Ghana has been a peaceful country in the sub-region, these indiscriminate attacks make Ghanaian tourist destinations susceptible to sub-regional collateral damage. Law enforcement might not be useful in the West African destinations, and this can impact negatively on tourist safety. On the other hand, in a study done by Tran and Bridges (2009), it was observed that in a destination where the law enforcement is effective coupled with government officials who support economic growth emerging from tourism it attracts increasing numbers of foreign tourists to that country. In their studies on "tourism and crime in 46 European nations," it was concluded that lesser crime rates against persons as well as higher security might be the product of tourism and economic development. In West Africa, so far as law enforcement is concerned, there is much room for improvement.

\section{Issues that influence tourists' safety at a destination}

Harassment is a prominent feature of the life cycle of tourism growth as a destination progresses from informal phase to consolidation and acceptance and many reports of the most sustained complaints come from popular, high-density resort areas where tourism is highly institutionalised (Kozak et al., 2007). Tourists have a way of observing a destination sometimes through the internet and gossip before they travel there. Tourists are predisposed to react based on their perceptions which are sometimes false. Pizam and Fleischer (2002), observe that individual tourists' actions make them susceptible to harassment. For example, tourists go to places where locals will not dare to go; their way of dressing and how they react to certain circumstances expose them to so many risks. Tourists would mostly want to go out at night because of the desire to have an authentic experience and to have fun, making themselves easy targets for criminals and offenders waiting to take advantage of them.

Harper (2001) identifies another behaviour-cause that can be related to the kind of friends tourists keep to themselves while at the destination. Since the language barrier can be a big problem for the tourists and in the attempt to trying to cope may attach themselves to some natives to feel secure and safe. Consequently, sometimes these friends turn out to be criminals who wait for the right moment to take advantage of the tourists (Pizam \& Mansfeld, 1996). At a particular time, a destination may be crowded with foreigners who come to share resources with locals as well and disturb the peaceful nature of the place (Morrison, 2012). Also, there have been cases where some sites and facilities are built up only for tourists and become a no-go area for the local people in the community. This situation compels the locals into acting up towards the very people who disturb their peace. Since the tour is filled with anxiety which may result in psychological and physical reflections of one's home environment, the tourist may behave, understand and react differently to the situation which may generate adverse reactions from the locals including harassment.

\section{Tourists' perception of safety}

Tourists develop a negative impression of a destination if they feel unsafe or threatened at a tourist facility while at the destination. This situation can severely affect the destination's tourism industry and image and can end up in the reduction of numbers to the area in question. George (2003) claimed that this reduction in arrivals could happen when:

- Potential tourists decide not to visit the destination because its reputation for chalking a high crime rate is rife. 
- Tourists feel unsafe at a destination and are not willing to participate in activities outside their lodging facilities.

- Tourists who have ever been threatened or felt unsafe at a destination are not likely to return to the place for leisure and quite unfortunate are not expected to recommend the destination to other potential tourists.

\section{The role of safety to the destination's image}

Little destination knowledge by tourists and the perceived negative reflection generated by poverty, political instability and sometimes terrible humanitarian circumstances (Grosspietsch, 2006) has been among the critical problems when there are high tourist activities. Undoubtedly, destination image has influences on tourist travel decision-making, cognition and behaviour at a destination as well as fulfilment or satisfaction levels and remembrance of the experience. Interestingly, memories and reflections of tourists after the trip to a destination complement the original adventures and desire for a repeat visit. Consequently, tourist destination images play a significant role in tourists' safety since these images influence both the decision-making behaviour of potential tourists and the level of satisfaction concerning the tourist destination.

Tourists depend profoundly upon the image of a particular destination when considering and choosing various holiday destinations. Due to broader choice and the diversity of tourist-destinations, modern-day tourists are likely to select holidays that offer total satisfaction of their travel desires and value for money. A tourist-destination having the right product alone is not enough to favourably compete in the tourism market. The expectations and needs of tourists must be considered whether or not the image is an actual illustration of what a destination has to offer the traveler or not, is less significant than the existence of the image in the minds of the potential tourists (Jenkins, 1999; Strydom \& Nel, 2006; Ilieș et al., 2018, 2019; Indrie et al., 2019). According to Sönmez and Sirakaya (2002), "positive images of a destination help the policy planner and tour operators to create awareness, and this can serve as the distinguishing factor among competing destinations". Safety and security are without any doubt the sine qua non-primary conditions for the healthy tourism development of every destination, region or country and thus serves as the fundamental determinants of its growth (Mopeli, 2009). Without these conditions, destinations cannot compete successfully in the global market of tourism even if they present through their marketing campaigns, the most attractive and the excellent quality natural and human-made attractions like Castles in Elmina and Cape Coast and the Canopy walkway in Kakum National Park in the Central Region of Ghana.

\section{Tourists' pre-trip conception of safety}

In the opinion of Reisinger and Mavondo (2005), it is vital to understand how potential tourists experience their environment or destination in terms of safety to create a conducive environment for tourism development. Sjöberg (2002) explains that safety and physical security are prerequisites for healthy tourism development of every destination. In contemporary tourism issues, safety and security for international travelers have become a global issue, and some reasonable discussion and media space have been assigned to its discourse. This media coverage, coupled with other factors informs the potential tourists of what is likely to be met when they decide to visit a destination at the expense of the other. Mansfeld (2006) observes that inadequate personal safety is seen as a significant deterrent to the international traveler or tourists. Foreign tourists, who feel that their security cannot be assured and could be compromised, may perceive the destination as unsafe to visit. Countries most at times issue out directives to their citizens warning them of not going to some destinations for tourism. For example, Australia issued a warning about inadequacy of safety in some high-risk nations such as Malaysia, Singapore and Thailand (Mopeli, 2009). 


\section{Influence of tourist satisfaction on repeat visits}

According to Oliver (1981), in the hospitality and tourism industry, the pleasure of tourists is examined as part of tourists' post-purchased and consumed evaluation of the destination. Consequently, positive satisfaction has a positive effect on tourists repurchase decision making (Gotlieb et al. 1994). It is noted in the cornucopia of academic literature that gratification of a tourist at a destination is a good prediction pointer of the tourists' repurchasing and revisiting choices (Choi \& Chu, 2001; Petrick, 2002; Tam, 2000) and consequently as opined by Petrick \& Backman (2002) tourists who have a positive adventures during the period of one recreational activity will possibly repeat the tourism expedition. Remarkably, the direct correlation between tourist safety and tourist satisfaction has received little attention in the existing literature in tourism. Petrick, (2002) and Yi, (1990), for instance, have done some revisions on consumer satisfaction but absent is the above correlation factor.

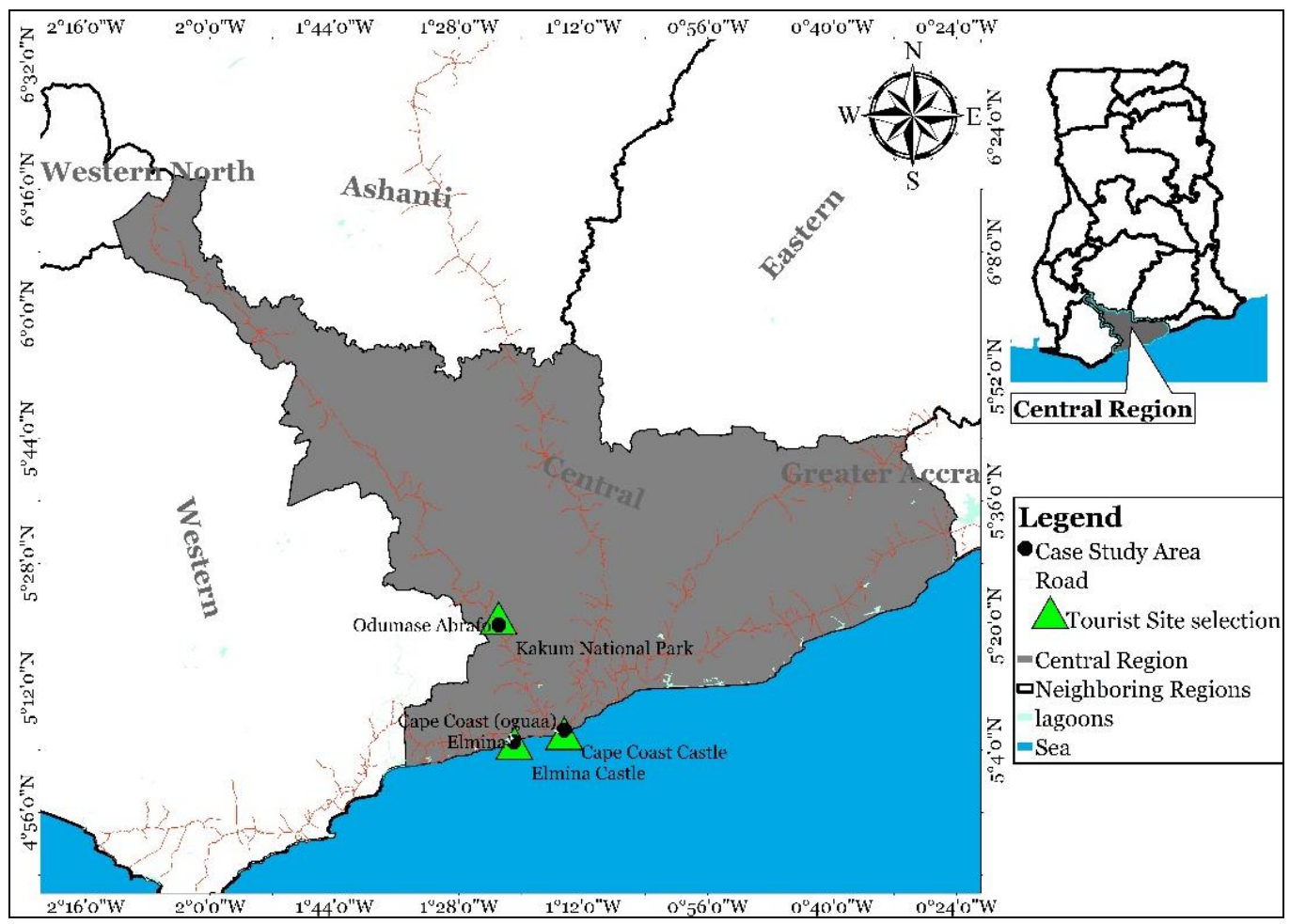

Figure 1. The map of the study area - Cape Coast, Elmina and Kakum (Source: Department of Geography and Regional Planning, GIS Remote Sensing and Cartography Unit, University of Cape Coast, Ghana, 2019)

Moreover, the limited works that did some analysis on the consequences of satisfaction like Anderson and Sullivan, (1993) and Baker \& Crompton (2000) that worked on intentions for repeat visit still did not work on the direct influence of tourist safety on tourist satisfaction. Also, it has been proposed by Soderlund (1998) that an increase in consumer satisfaction would not necessarily result in the same rise in consumer loyalty to a service or product. In 2007, Lee et al. (2007) did some study but did do not identify an essential relationship between satisfaction and the tourist's intention to revisit the tourism event. One can say that the intensity of the relationship 
between tourist' satisfaction and repeat visit can vary, depending on the service or product being examined and depending on other issues that can also affect the formation of an individual tourist' expectations (Lee et al. 2007) but the impact of tourist safety is still a stronger issue in this debate of tourists' satisfaction (Imbeah \& Bujdosó, 2018).

\section{MATERIALS AND METHODS The Case Study Area}

Cape Coast Castle is found in Cape Coast in Ghana, and its location is shown in Figure 1 below. In Figure 1 are shown the map of the Central Region in Ghana. Figure 2 also shows the aerial view of the Cape Coast Castle on the Atlantic Coast of Ghana.

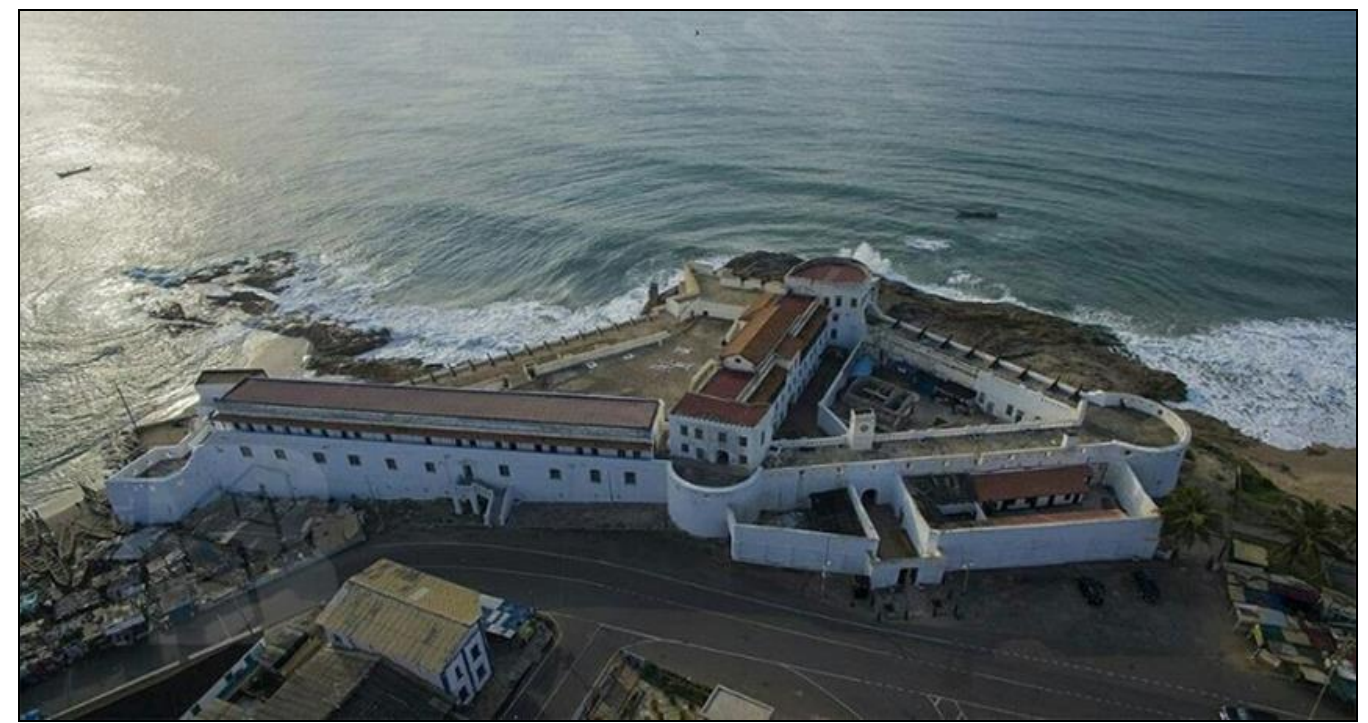

Figure 2. Aerial view of Cape Coast Castle on the Atlantic Coast (Source: GMMB, Ghana, 2018)

Cape Coast Castle was built by the Portuguese in 1555 to be used purposely for trading between the European and Ghanaian merchants. During the British colonial time, Cape Coast Castle served as the seat of the then governor and a school premises. Since the attainment of Ghana's independence in 1957, the Castle has remained as a museum with an arts and craft gift shop. Cape Coast Castle is now designated and classified as a World Heritage Monument under UNESCO (Anquandah, 1999). Elmina Castle is found in Elmina, and its location is shown in Figure 1 above. Figure 3 below shows the aerial view of the Elmina Castle on the Atlantic Coast of Ghana. All the building blocks needed for the construction were shipped from Portugal to Elmina. The Castle was built in 1482 .

The structure became the first pre-fabricated building of European origin to have been planned and executed in Sub-Saharan Africa purposely to facilitate trading between the Portuguese and Ghanaian merchants. Since 1814 the Castle has been used for several purposes in Ghana. Elmina Castle has become a great tourist resource in Ghana because it draws a higher number of travelers and tourists. The Castle is a place of pilgrimage for many Africans in the diaspora searching for their root in Africa. The Castle is now preserved as a Ghanaian national museum. It was designated and classified as a World Heritage Monument under UNESCO in 1979 (Anquandah, 1999). Kakum National Park is a rain forest park very close to the above two Heritage sites in the Central Region of Ghana. KNP is between Cape Coast and Elmina townships, about 15km apart. 
This park was established in 1992 at the resourcefulness of the natives and not by the State Department of wildlife in Ghana (Wellington, 1998). KNP also has a variety of birds and a large variety of butterflies. KNP has a treetop canopy walkway made of seven long bridges and four short bridges. This forest facility is known to be the first of its kind in Africa (Imbeah \& Bujdosó, 2018). The location of Kakum National Park is shown in Figure 1 above. Figure 4 below shows the snapshot of the Kakum Canopy Walkway in the forest.

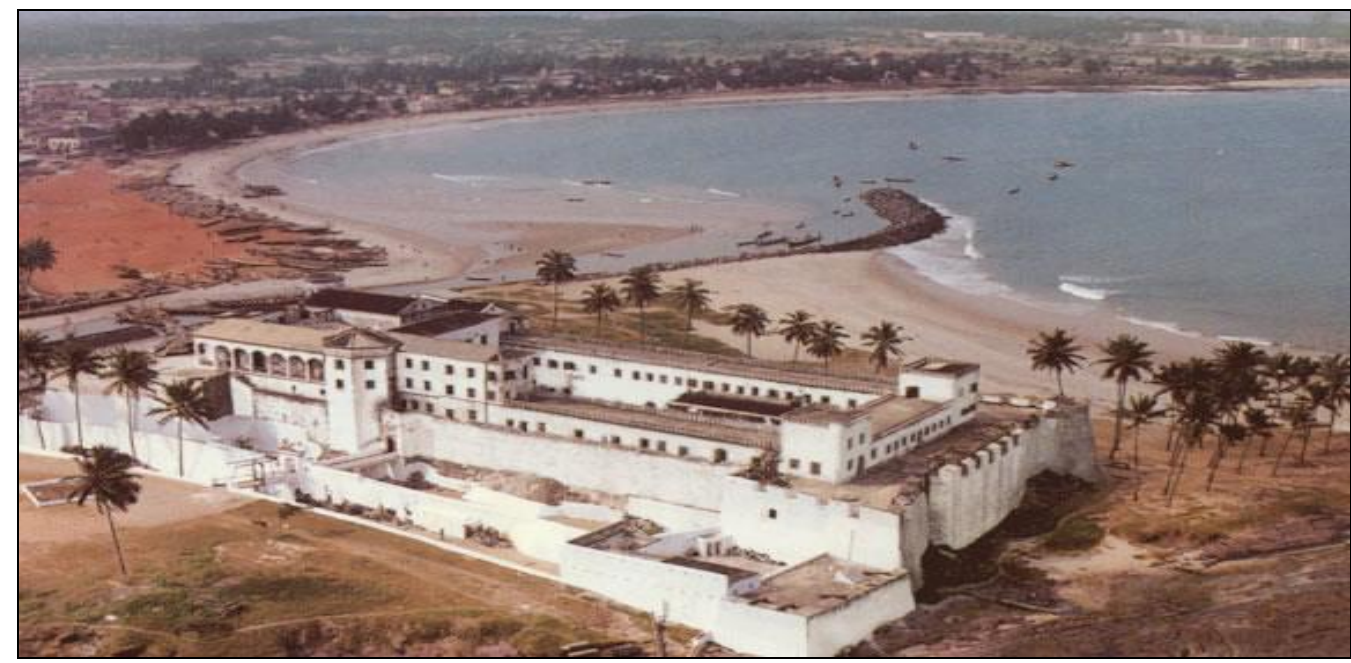

Figure 3. Aerial view of Elmina Castle on the Atlantic Coast (Source: GMMB, Ghana 2018)

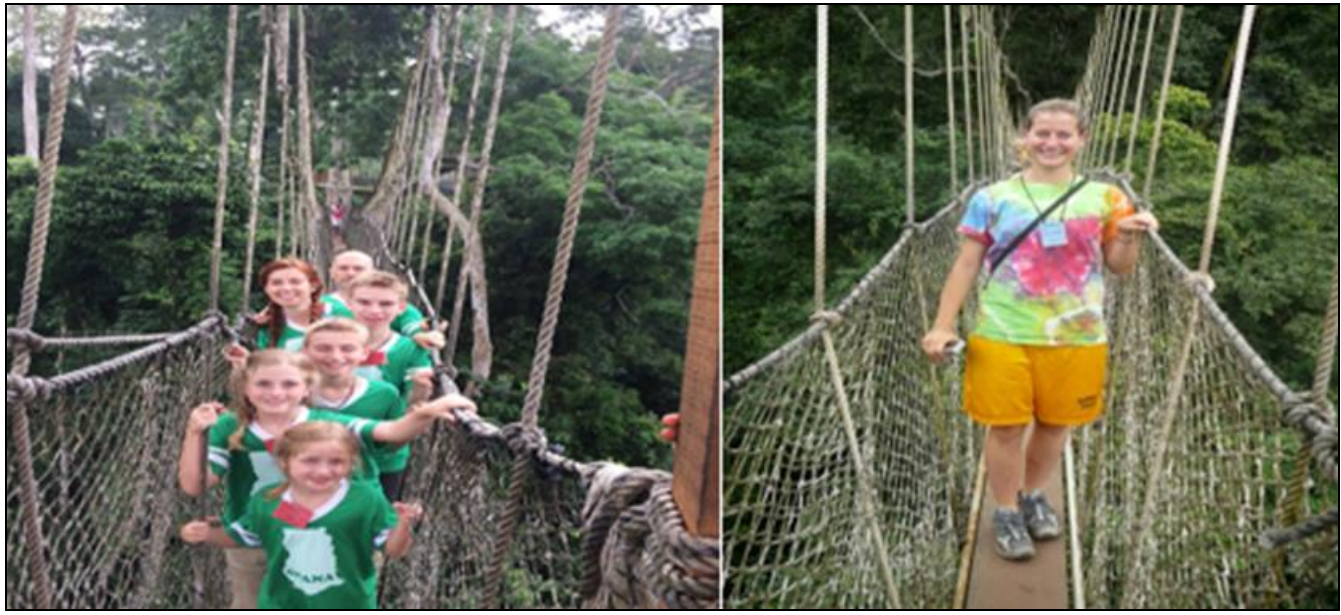

Figure 4. Canopy Walkway at KNP (Source: KNP, Kakum, Ghana, 2018)

Furthermore, by observation of tourist consumer behaviour, these three tourist facilities have formed a trio of heritage-ecological tourist destination on the coast of Ghana. Most inbound tourists, especially the Afro-Americans in the diaspora, visit them before leaving the Central Region of Ghana. Hence, this is the reason these facilities and patrons were chosen for the study on assessing tourists' perceptions of safety in a destination. They have now become iconic and established sites in Ghana (Frempong et al. 2015). This work was a case study of two historical heritage sites and one ecological 
heritage site in the Central Region of Ghana. These facilities are the most visited sites patronised by inbound tourists in Ghana; they have become iconic of the country. Snapshots of these sites and the map of the case study area are also displayed in the study. Field assistants were trained on the questionnaire administration, and they were educated on ethical issues surrounding the survey. Descriptive statistical presentations and inferential statistical measures were employed in the analysis of the field data.

\section{Sampling and Survey Instrument}

The work used a descriptive research design. This type of design did not allow the key variables to be manipulated, but it described and interpreted what existed on the field of study as opined by Creswell (2009) and Babbie (2013). They propose that descriptive study design is concerned with conditions or interrelationships "that exist, opinions that are held, processes that are going on, effects that are evident and trends that are developing in the field". Random responses of 515 tourists were surveyed for the study. Mostly only international tourists do visit the trio of facilities selected within the period of visit before going back to their origin; hence the most significant percentage (97\%) of the respondents being non-Ghanaians. Random purposive sampling technique was employed because there was no reliable data on tourists to construct a sampling frame. Selfadministered questionnaires that contained both open and closed-ended questions were used. This instrument was appropriate because most inbound tourists to Ghana to some extent, express themselves in the English language. Also, it helped ensure the independence and anonymity of respondents in the study. For tourists who could not express themselves in English language, research assistants helped them answer the questions. The questionnaires were administered to tourists who had visited these three facilities during the tourism peak season in the Central Region, between June and September 2018. The survey questions that formed core constructs in the questionnaire included: What were the precautionary measures did tourists undertake before travelling and during their stay at the destination? What were the security facilities the tourists find at the attraction sites visited? And what were the general impressions of tourists about safety at the destination? The research assistants used the tool of observation to verify the security facilities identified by the tourists. Before the data collection permission was sought from the managers and heads of the selected attraction sites and facilities.

This permission helped ensure a good rapport with the workers at the attraction sites for easy accessibility to the sites and also to the tourists who visited. The data were analysed with the use of IBM Statistical Product for Social Science (SPSS) software version 20. The data from the field were edited and cleaned to do away with partially filled questionnaires which could affect the validity of the results.

The data was then coded and entered into the SPSS software for analysis. Descriptive statistical presentations which included pie charts, bar charts, crosstabulations and frequencies were run to represent various background characteristics of respondents, their perceptions of safety, among others. Inferential statistical measures like Chi-Square Test of Independence were employed to test for relationships between background characteristics of tourists and their perceptions of safety and security at the destination, purpose of travel and overall impressions and assessment of safety.

\section{RESULTS AND DISCUSSIONS}

\section{Demographics}

A total of 515 respondents was sampled during the survey, but not every respondent answered all the six attributes as shown in Table 1 (gender; age; nationality; the level of education; marital status and employment status) under demographics. It was observed that a little more than half of the respondents $(58.8 \% ; 290$ tourists) were 
females whiles approximately two out of five of them (41.2\%; 209 tourists) were males; this indicated that most of the tourists involved in the study were females. Also, close to two-thirds of the respondents (63.1\%) were between the ages of 18 - 33 years. About one out of every ten of the respondents (10.6\%) was either 50 years or more; this indicated that the tourists who visited the attraction sites at the time of the study were predominantly the youth of not more than 41 years of age, namely 182 tourists were between 18-25 years; 131 tourists fell between 26 - 33 years; 85 tourists were between 34 41 years; 45 tourists were between 42-49 years; 30 respondents were between 50-57 years; 12 respondents were between 58-65 years; 11 respondents were $65+$ years.

The tourists involved in the study were virtually international, and the reason was that almost all of the respondents (97.1\%; 500 tourists) were non-Ghanaians with only $2.9 \%$ (15 tourists) of them being Ghanaians. On the education front, most of the respondents $(42.3 \%$; 212 tourists) indicated that they had attended either a university or a college with only a few of them $(4.2 \% ; 21$ tourists) having attained their primary education. Also, close to one-third of the respondents (30.3\%; 152 tourists) reported that they had schooled up to the post-graduate level. Furthermore, 23.2\% (116 tourists) indicated that they had had a high school education. These imply that almost all the tourists have had, at least, a high school education. Therefore, their impressions about issues on tourist safety can be reliable and taken for consideration for tourist safety and planning. Furthermore, more than half of the respondents (61.3\%; 307 tourists) reported that they were single whiles a little over one-third of them $(34.5 \% ; 173$ tourists) said that they were married. Similarly, a few of the respondents $(4.2 \%)$ said that they had ever married (divorced (3.4\%; 17 tourists) and widowed (0.8\%; 4 tourists). These indicate that most of the tourists involved in the study did not have any marital responsibilities and thus, were able to move freely or venture into adventures like recreational activities and vacation.

The various occupations were grouped into two groups of unemployed (made up of the unemployed, student and retired) and employed (made up of all other trades). More than half of the respondents $(58.8 \% ; 291$ tourists) indicated that they had occupation while a good number of them $(41.2 \% ; 204$ tourists) reported that they were not; this meant that engaging in tourism is not necessarily for the employed and it might mean that those unemployed tourists who travelled on their own had already saved funds.

\section{Security facilities at tourist sites}

The attraction sites visited by the respondents were: Elmina Castle, Cape Coast Castle, Kakum National Park, Hanson's Cottage, Monkey Forest Resort, Stingless Bee Centre and Elmina Lagoon in the Cape Coast tourist destination in the Central region of Ghana. 32.2 \% of respondents indicated that the tourist attraction sites visited had the presence of security guards at post; $28.7 \%$ of the respondents reported that the attraction sites visited had directional signs installed; $19.7 \%$ indicated that safety signs were installed at the tourist attraction sites visited; $8.7 \%$ indicated the observation of CCTV cameras at the tourist facilities visited; $6.5 \%$ of the respondents stated that they saw alarm system at the sites; $3.6 \%$ specified that there was an observation of safety deposit boxes and others $0.6 \%$ indicated observed other facilities not classified among the above in the tourist facilities visited. These showed that most of the tourist attraction sites visited had security facilities such as safety guards, directional signs and safety signs installed in place. What was not too specific was whether the CCTV cameras and the safety deposit boxes were serviced periodically or not.

It was observed that safety installations in these facilities were either not working or non-existent and that there was no active supervision for repairs. Table 2 shows that a little more than half of the tourists aged either 50 years or more indicated that they visited the destination for vacation $(51.7 \%$ for $50-57$ years; $75.0 \%$ for $58-65$ years and 
$72.7 \%$ for more than 65 years). Similarly, most of the tourists between the ages of 18 and 49 years indicated that they travelled to the destination for vacation $(39.0 \%$ for 18 25 years; $45.2 \%$ for $26-33$ years; $48.8 \%$ for $34-41$ years and $47.7 \%$ for $42-49$ years) and to visit their families and friends (32.6\% for $18-25$ years; $24.6 \%$ for $26-33$ years; $22.5 \%$ for $34-41$ years and $20.5 \%$ for $42-49$ years). On the other hand, none of those aged 50 years or more travelled to the destination for educational purposes whiles only a few of them (8.3\% for 58-65 years and 9.1\% for those aged more than 65 years) went there for official purposes. These results meant that there are no significant differences in the tourists' age and their reasons for travelling to the destination.

Table 1. Demographic characteristics of the survey respondents (tourists)

(Source: Fieldwork, Imbeah, 2018)

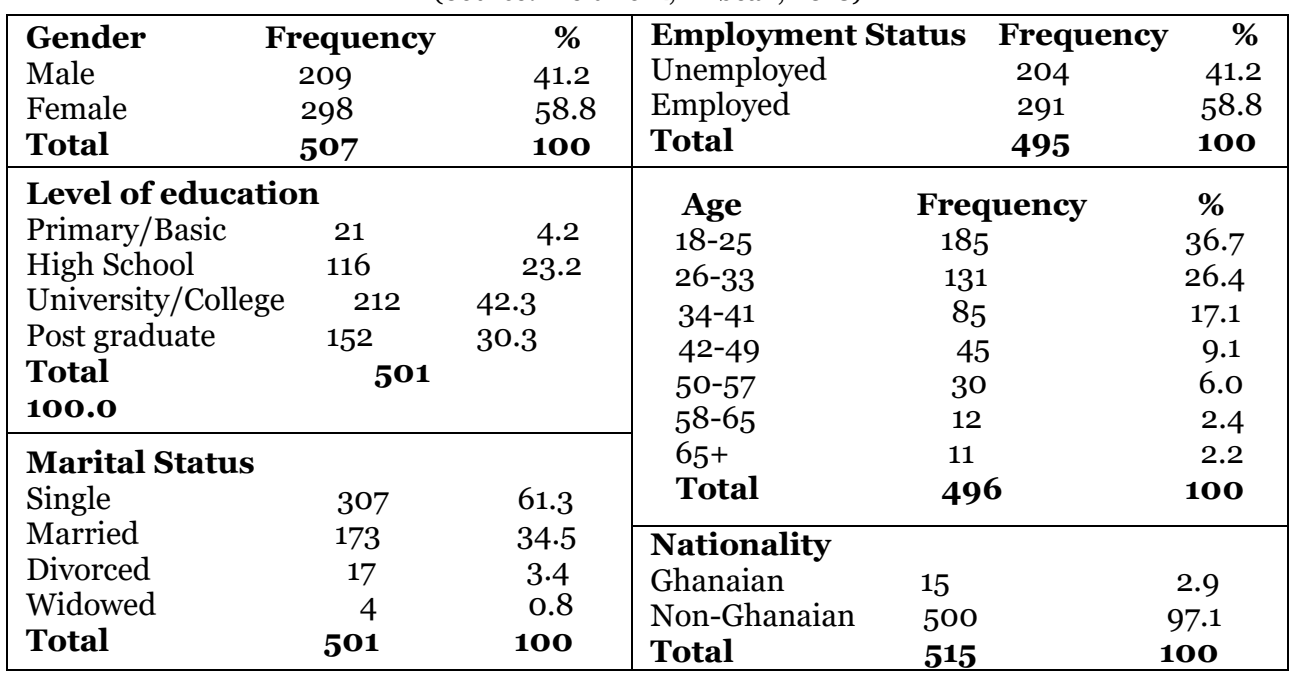

Table 2. Purposes of tourists' visits based on their age (Source: Fieldwork, Imbeah, 2018)

\begin{tabular}{|l|c|c|c|c|c|c|c|c|c|c|}
\hline \multirow{2}{*}{$\begin{array}{c}\text { Age } \\
\text { (in years) }\end{array}$} & \multicolumn{7}{|c|}{$\begin{array}{c}\text { Business/ } \\
\text { Conference }\end{array}$} & \multicolumn{2}{c|}{ Education } & \multicolumn{2}{c|}{ Vacation } & \multicolumn{2}{c|}{$\begin{array}{c}\text { Visit } \\
\text { friends/family }\end{array}$} & \multicolumn{2}{|c|}{ Total } \\
\cline { 2 - 12 } & Freq. & $\%$ & Freq. & $\%$ & Freq. & $\%$ & Freq. & $\%$ & Freq. & $\%$ \\
\hline $18-25$ & 13 & 7.6 & 36 & 20.9 & 67 & 39.0 & 56 & 32.6 & 172 & 100.0 \\
\hline $26-33$ & 13 & 10.3 & 25 & 19.8 & 57 & 45.2 & 31 & 24.6 & 126 & 100.0 \\
\hline $34-41$ & 15 & 18.8 & 8 & 10.0 & 39 & 48.8 & 18 & 22.5 & 80 & 100.0 \\
\hline $42-49$ & 9 & 20.5 & 5 & 11.4 & 21 & 47.7 & 9 & 20.5 & 44 & 100.0 \\
\hline $50-57$ & 5 & 17.2 & 4 & 13.8 & 15 & 51.7 & 5 & 17.2 & 29 & 100.0 \\
\hline $58-65$ & 1 & 8.3 & 0 & 0.0 & 9 & 75.0 & 2 & 16.7 & 12 & 100.0 \\
\hline $65+$ & 1 & 9.1 & 0 & 0.0 & 8 & 72.7 & 2 & 18.2 & 11 & 100.0 \\
\hline Total & 57 & 12.0 & 78 & 16.5 & 216 & 45.6 & 123 & 25.9 & 474 & 100.0 \\
\hline
\end{tabular}

A further analysis was conducted to find out if the ages of the tourists had any form of relationship with their purposes for travelling to the destination. The result of the subsequent analysis is presented in Table 3. It can be observed from Table 3 that there were significant enough differences in the reasons for which the tourists travelled to the destination based on their ages (with a Pearson's Chi-square coefficient of 30.782 and corresponding $p$-value of 0.031). Furthermore, with a Cramer's V coefficient of 0.147 and a corresponding $p$-value of 0.031 , it can be observed from Table 3 that the 
strength of the association between the tourists' ages and their reasons for travelling to the destination was slightly excellent and significant. This result implies that the age of the tourists influences their purposes for going to the destination.

Table 3. Chi-Square tests on purposes of tourists' visits

based on their age (Source: Fieldwork, Imbeah, 2018)

\begin{tabular}{|l|c|c|}
\hline Tests & Value & Approx. Sig. \\
\hline Pearson Chi-Square & 30.782 & 0.031 \\
\hline Phi & 0.255 & 0.031 \\
\hline Cramer's V & 0.147 & 0.031 \\
\hline No. of Valid Cases & 474 & \\
\hline
\end{tabular}

Table 4. Safety measures employed before travelling to the destination

(Source: Fieldwork, Imbeah, 2018)

\begin{tabular}{|l|c|c|c|}
\hline \multicolumn{1}{|c|}{ Safety measures } & Responses & Per cent of \\
\cline { 2 - 3 } & $\mathrm{N}$ & Per cent & Respondents \\
\hline Acquired comprehensive travelers' health insurance & 308 & 20.5 & 72.1 \\
\hline $\begin{array}{l}\text { Assembled suitable medical/first-aid kits and toilet items for the } \\
\text { duration of visit }\end{array}$ & 242 & 16.1 & 56.7 \\
\hline Assessed the health risks associated with travelling to the destination & 284 & 18.9 & 66.5 \\
\hline Consulted travel medical clinic or practitioner before travelling & 225 & 14.9 & 52.7 \\
\hline Took some vaccinations before travelling & 150 & 10.0 & 35.1 \\
\hline $\begin{array}{l}\text { Obtained prescribed medicine according to the duration of visit at } \\
\text { destination }\end{array}$ & 89 & 5.9 & 20.8 \\
\hline Brought bottled water/drinks for the duration of stay & 105 & 7.0 & 24.6 \\
\hline $\begin{array}{l}\text { Sought information on the health risks of destination from tour } \\
\text { operators, travel agents, airlines }\end{array}$ & 34 & 2.3 & 8.0 \\
\hline Sought information on traffic, animals and sports related accidents & 60 & 4.0 & 14.1 \\
\hline Other & 9 & 0.6 & 2.1 \\
\hline \multicolumn{1}{|c|}{ Total } & 1506 & 100.0 & 352.7 \\
\hline
\end{tabular}

It must be noted that in responding to safety measures employed before travelling to the destination by the tourists, respondents provided more than one answer to a question and so the percentages are not calculated based upon the number of respondents but on the number of responses. Table 4 shows that $20.5 \%$ of the reactions reported that they acquired comprehensive travelers' health insurance; $18.9 \%$ assessed the health risks associated with travelling to the destination; $16.1 \%$ assembled suitable medical/first-aid kits, and toilet items for the duration of visit and $14.9 \%$ consulted a travel medical clinic or a practitioner before travelling to the destination. 35.1\% took vaccination before moving to the target; $7.0 \%$ went with bottled water/drinks; $5.9 \%$ indicated moving with medicines which would make them through the duration of their visit to the destination.

These suggest that most of the tourists that visited Ghana took precautionary safety measures such as acquiring comprehensive travelers' health insurance; assessing the health risks associated with their travelling; assembling suitable medical/first-aid kits and toiletries for the duration of their visit, and consulting a travel medical clinic or a practitioner as well as vaccinating themselves before travelling to the destination; this confirms the observation made in the literature that African destinations are generally perceived to be unsafe for tourists (Brown, 2000; Levantis \& Gani, 2000; Boakye, 2012) hence, various safety measures were employed by tourists before travelling to the destination. It must be noted that in responding to adopted safety measures whiles at the destination by the tourists, respondents provided more than one answer to a question and so the percentages are not calculated based upon the number of respondents but on the 
number of responses. It is shown in Table 5 that, $31.3 \%$ indicated eating only foods that were well-cooked or well-packed; $30.7 \%$ reported buying first-aid kits and toilet items whiles living at the destination; $16.3 \%$ specified sleeping under a treated mosquito; $11.6 \%$ said drinking only well-sealed bottled water or drinks from certified producers; as they lived at the destination; $4.2 \%$ determined boiling their drinking water before drinking if they felt doubtful about its safety. These indicate that the tourists had very much been concerned about their safety while staying at the destination.

Table 5. Adopted safety measures whiles at the destination (Source: Fieldwork, Imbeah, 2018)

\begin{tabular}{|l|c|c|c|}
\hline \multirow{2}{*}{ Safety measures } & \multicolumn{2}{c|}{ Responses } & $\begin{array}{c}\text { Per cent of } \\
\text { Respondents }\end{array}$ \\
\cline { 2 - 4 } & $\mathrm{N}$ & Per cent & 82.1 \\
\hline Ate only cooked/well-packaged foods & 340 & 31.3 & 80.4 \\
\hline Bought first-aid kits and toilet items & 333 & 30.7 & 80.8 \\
\hline Slept under a treated mosquito net & 177 & 16.3 & 42.8 \\
\hline $\begin{array}{l}\text { Consumed only well-sealed bottled water or drinks } \\
\text { from certified producers }\end{array}$ & 126 & 11.6 & 30.4 \\
\hline Took boiled drinking water if its safety is doubtful & 46 & 4.2 & 11.1 \\
\hline \begin{tabular}{l|c|} 
Always used disinfectant to clean hands after every \\
handshake/touching something
\end{tabular} & 64 & 5.9 & 15.5 \\
\hline \multicolumn{1}{|c|}{ Total } & 1086 & 100.0 & 262.3 \\
\hline \multicolumn{2}{|l|}{} \\
\hline
\end{tabular}

Table 6. Perceptions of tourists on safety at the destination and their perceived safety before travelling (Source: Fieldwork, Imbeah, 2018)

\begin{tabular}{|l|c|c|c|c|c|c|}
\hline & Mean & $\mathrm{N}$ & $\begin{array}{c}\text { Std. } \\
\text { Dev. }\end{array}$ & $\begin{array}{c}\text { Std. Error } \\
\text { Mean }\end{array}$ & Correlation & Sig. \\
\hline $\begin{array}{l}\text { Tourists' overall perception of } \\
\text { safety at destination }\end{array}$ & 1.82 & 467 & 0.586 & 0.027 & 0.370 & 0.000 \\
\hline $\begin{array}{l}\text { Tourists' perception of safety at } \\
\text { the destination before their visit }\end{array}$ & 1.91 & 467 & 0.659 & 0.031 & & \\
\hline
\end{tabular}

Notes: 1-1.49 = Highly safe; $1.5-2.49$ = Safe; $2.5-3.49$ = Slightly safe; $3 \cdot 5-4 \cdot 49=$ Not safe; $4 \cdot 5-5=$ Highly unsafe

It can be observed from Table 6 that there was a mean value of 1.82 for the respondents' responses on "What is your overall perception of tourists' safety at this destination?" On the overall, most of the tourists found the destination as safe. Regarding the tourists' general perception of the safety of the sites before their visit, most of them indicated that they had formed a reliable impression about the area between their travels. Table 6 also shows that there was a relatively strong positive relationship between the tourists' safety expectations of the destination and their actual overall perception of safety at the place (with a Pearson's Correlation Coefficient of 0.370 and a corresponding $p$ value of 0.000 ). Since $p=0.00<0.05$, it can be said that there is enough statistical evidence to infer that as the level of the tourists' safety satisfaction increased, their safety expectations also increased, possibly for future visits. The notion that African destinations are generally unsafe destinations for tourists (George, 2003; Levantis \& Gani, 2000) is contrasted by the responses of these tourists in this study at least in the Central Region of Ghana. This result is confirmed by the research done in West Africa by Awaritefe, (2004) that perceptions change completely after visitation to the tourist destination.

\section{CONCLUSION}

As opined by Baker \& Stockton (2014) in areas and tourist facilities where safety devices are mounted, potential offenders are likely to notice probabilities of detection greater and opportunities for escape more limited in those facilities that are purposely 
designed with prevention in mind. In this vein, tourists cannot be quietened into a false sense of security due to the mere presence of skilled guardians visibly stationed in the facility as observed in this destination. If an effort is not made to concurrently reduce the number of motivated criminals from the destination area, simply adding security workers may not produce the intended restraining effect on the part of the offenders. Their results on the study of tourism and crime in America in two major American tourist cities showed that there was a significant correlation between law enforcement employee numbers and reduced crime (Baker \& Stockton, 2014). They added that law enforcement and private security personnel are essential to deter crime against tourists and visitors. However, one can say that in Ghanaian situation, law enforcement is weak, and this might be the weakest link in the effort to work to reduce the crime committed against tourists. Over time this can influence tourists' purposes for travelling to this destination which is the tourism hub in Ghana. Levantis and Gani (2000) observed that governments of developing nations (including Ghana) do accept economic gains associated with tourism promotion; so, they should therefore seriously work on the issues of crime and law and solve problems when they arise to stem the loss of revenue from the tourism sector.

It was observed that in the three tourist sites surveyed, safety issues were not highly promoted except the treetop canopy walkway, which is a unique facility at the Kakum National Park. Albeit the tourists saw some safety gadgets in the tourist facilities visited, it was observed that safety installations in these facilities were either out of order or non-existent and there was no supervision, evaluation or repairs of these installations. It is recommended that GTA should add the inspection, installation and repairs of such safety equipment in unannounced routine checks in all the tourist and hospitality facilities in the region. The various tourism-related bodies in the Central Region like Ghana Tourism Authority (GTA), World Conservation Trust, Road and Safety Authority, Ghana Fire Service and Ghana Police Service should be tasked to help maintain safety and security at tourist sites. Training of the safety/security guards should be regular and standard with recognised safety/security agency as a permanent supervisory-trainer. From the observation made at the destination, it would be highly beneficial if GTA can initiate safety exercises in these three facilities to produce a digital-tourist safety documentary about each facility. Application of such digital-technologies promoted in the social media in tourism promotion will help instil surety in the preparation and choice of destination-sites of potential tourists. The study proposes that GTA must draft strategies and policies to curtail unsafe conditions in tourist destinations and improve safety in the region. Tourism stakeholders in this destination can be persuaded to adopt and maintain surveillance technology like CCTV cameras and run safety training for the destination workers. In the longer-term government can put plans in place to install this technology in priority areas throughout the region.

However, any lapse in any tourist destination in the sub-region can equally affect the image of the entire regional tourism development. Therefore, it is expected that this study will lead to further research on tourist safety and security within Ghana and her neighbouring countries in West Africa to reflect the regional position on tourism safety; this is because the following questions must be answered: To what extent can tourists undergo pre-trip preparations before traveling to a destination in West Africa? What type of measures must tourists adopt to stay and enjoy their trips to West Africa? What is the level of cooperation among West African countries in terms of tourist safety and security?

In conclusion, since Ghana has for an extended period maintained a peaceful political, tourism and social ambience in the West African sub-region, international safety standards in developing and managing tourism facilities should be strictly observed. All tourism agencies should be coordinated by GTA and supported to work for the common good. In the drafting of local tourism planning in the Central Region of Ghana, the 
responses of tourists about tourists' safety and security should be considered. Since tourists' purpose of traveling does not influence tourists' perception of safety at the attraction sites, the various stakeholders such as the tourism agencies, tour operators and tourism-related enterprises must take the advantage to provide other tourism structures for improving the life cycle of tourism products and activities in the region.

\section{Acknowledgements}

The Stipendium Hungaricum Programme supported this work.

\section{REFERENCES}

Anderson, E. W. \& Sullivan, M. W. (1993). The antecedents and consequences of customer satisfaction for firms. Marketing Science, Vol. 12, No.2, pp. 125-142.

Anquandah, K. J. (1999). Castles and forts of Ghana. Ghana Museums and Monuments Board. Accra: Ghana.

Awaritefe, O.D. (2004). Motivation and other considerations in tourist destination choice: A case study of Nigeria. Tourism Geographies, Vol. 6, No. 3, pp. 303-330.

Babbie, E. (2013). The practice of social research. 13th ed. Wadsworth: Cengage Learning.

Baker, D. A. \& Crompton, J. L. (2000). Quality, satisfaction and behavioural intentions. Annals of Tourism Research, Vol. 27, No. 3, pp. 785-804.

Baker, D. \& Stockton, S. (2014). Tourism and Crime in America: A preliminary assessment of the relationship between the number of tourists and crime, two major American tourist cities. International Journal of Safety and Security in Tourism, Vol. 5, pp. 1-25.

Boakye, K.A. (2012). Tourists' views on safety and vulnerability. A study of some selected towns in Ghana. Tourism Management, Vol. 33, No. 2, pp. 327-333.

Breda, Z. \& Costa, C. (2006). Safety and security issues affecting inbound tourism in PRC. Elsevier Butterworht-Heinemann, MA, 187-208.

Brown, O. (2000). Tourism and foreign investment in Africa. In P. Dieke (Ed.), The political economy of tourism development in Africa (pp. 274-284). New York: Cognizant.

Bujdosó, Z. (2009). The effect of the county border on the catchment area of cities in the example of HajdúBihar county Debrecen, Hungary: University of Debrecen, p. 211.

Bujdosó, Z., Dávid, L., Remenyik, B. \& Tóth, G. (2011). Connection between tourism and regional development on the Hungarian-Croatian border Central European Regional Policy and Human Geography, Vol. 2, pp. 27-40.

Bujdosó, Z.; Dávid, L. (2013) Extreme sports and other activities in tourism with special regard to the Mátra Mountain Journal Of Physical Education And Sport $13: 1$ pp. 39-45. , 7 p.

Bujdosó, Z., Dávid, L., Wéber, Z. \& Tenk, A. (2015). Utilization of Geoheritage in Tourism Development. Procedia - Social And Behavioral Sciences 188 pp. 316-324. , 9 p.

Cavlek, N. (2002). Tour Operators and Destination Safety. Journal of Tourism Research, Vol. 29, No. 4, pp. $457-534$.

Choi, T. Y. \& Chu, R. (2001). Determinants of hotel guests' satisfaction and repeat patronage in the Hong Kong hotel industry. International Journal of Hospitality Management, Vol. 20, No. 3, pp. 277-297.

Creswell, J. (2009). Research design: qualitative, quantitative and mixed methods approaches. Sage, Thousand Oaks: CA.

Ferreira, S. \& Harmse, A. (2000). Crime and tourism in South Africa: international tourists' perception and risk. South African Geographical Journal, Vol. 82, No. 2, pp. 80-85.

Frempong, F., Dayour, F. \& BondzI-Simpson, A. (2015). Visitor satisfaction with Ghana's tourist attractions. Oguaa Journal of Social Sciences, Vol. 3, pp. 104-124.

George, R. (2003). Tourists' perceptions of safety and security while visiting Cape Town. Tourism Management, Vol. 24, No. 5, pp. 575-585.

Gotlieb, J. B., Grewal, D. \& Brown, S.W. (1994). Consumer satisfaction and perceived quality: complementary or divergent constructs? Journal of Applied Psychology, Vol. 79, No. 6, pp. 875-885.

Grosspietsch, M. (2006). Perceived and projected images of Rwanda: Visitor and International tour operators' perspectives. Tourism Management, Vol. 27, pp. 225-234.

Gunaratna, R. (2016). Ivory Coast Attack: Africa's Terror Footprint Expands. A Journal of the International Centre for Political Violence and Terrorism Research, Vol. 8, No. 6, pp. 14-18.

Harper, D. W. (2001). Comparing Tourists' Crime Victimization. Annals of Tourism Research. Vol. 28, No. 4, pp. 1053-1056.

Ilieș, D.C., Oneț, A., Herman, G.V., Indrie, L., Ilieș, A., Burtă L., Gaceu, O., Marcu, F., Baias, S., Caciora, T., Marcu, A.P., Pavel, O.I., Costea, M., Ilieș, M., Wendt, J. \& Mihincău D. (2019), Exploring the indoor environment of heritage buildings and its role in the conservation of valuable objects, Environmental Engineering and Management Journal, December Vol. 18, No. 12, 2579-2586.

Indrie L., Ilieș, D. C., Oneț, A., Wendt, J. Ilieș, M., Timar, A., Ilieș, A., Baias, S. \& Herman, G.V. (2019). Indoor air quality of museums and conservation of textiles art works. Case study: Salacea Museum House, Romania, Industria textile, Vol. 70 No 1, pp 88-93.

Ilieș, D. C., Oneț, A., Marcu, F.M., Gaceu, O.R., Timar, A., Baias, S., Ilieș, A., Herman, G.V. Costea, M., Țepelea, M., Josan, I. \& Wendt, J. (2018). Investigations regarding the air quality in the historic wooden church 
in Oradea city, Romania, in Environmental Engineering and Management Journal, Vol.17, no11, pp.2731-2739, http://www.eemj.icpm.tuiasi.ro/pdfs/accepted/204_294_Ilie\%C8\%99_17.pdf.

Imbeah, N. \& Bujdosó, Z. (2018). Tourist safety and security in the Central Region of Ghana - overview and case study. Ecocycles, Vol. 4, No. 2, pp. 33-45.

Jenkins, O. H. (1999). Understanding and Measuring tourist Destination Images. International Journal of Tourism Research, Vol. 1, No. 1, pp. 1-15.

Kozak, M., Crotts, J. C. \& Law, R. (2007). The impact of the perception of risk on international travelers. International Journal of Tourism Research, Vol. 9, No. 4, pp. 233-242.

Lee, Y., Petrick, J. F. \& Crompton, J. (2007). The roles of quality and intermediary constructs in determining festival attendees' behavioral intention. Journal of Travel Research, Vol. 45, pp. 402 -412.

Levantis, T. \& Gani, A. (2000). Tourism demand and the nuisance of crime. International Journal of Social Economics, Vol. 27, No. 1, pp. 959-967.

Lisowska, A. (2017). Crime in tourism destinations: Research review. Tourism. Vol. 27, No. 1, pp. 32-39.

Mansfeld, Y. (2006). The role of security information in tourism crisis management: the missing link. MA: Elsevier, Butterworth-Heinemann.

Mansfeld, Y. \& Pizam, A. (2006). Toward a theory of tourism security. Tourism Management, 31(6): 855- 861.

Mátyás, Sz. \& Csege, Gy. (2019). Results of empirical research of surveillance camera systems in the light of subjective sense of security, Belügyi Szemle. Vol. 10, pp. 71-84.

Mopeli, M. J. (2009). Impacts of tourists' perceptions of safety and security of tourism marketing of Mpumalanga. (Master's thesis): Durban University of Technology.

Morrison, A.M. (2012). Marketing and Managing Tourism Destinations. London: Routledge.

Oliver, R.L. (1981). Measurement and Evaluation of Satisfaction Process in Retail Settings. Journal of Retailing, Vol. 57 , pp. 25-48.

Petrick, J. F. (2002). Experience use history as a segmentation tool to examine golf travelers' satisfaction, perceived value and repurchase intentions. Journal of Vacation Marketing, Vol. 8, No. 4, pp. 332-342.

Petrick, J. F. \& Backman, S. J. (2002). An examination of the determinants of golf travellers satisfaction. Journal of Travel Research, Vol. 40, pp. 252-258.

Pizam, A., \& Fleischer, A. (2002). Severity versus frequency of acts of terrorism: which has a larger impact on tourism demand? Journal of Travel Research, Vol. 40, pp. 337-339.

Pizam, A. \& Mansfeld, Y. (1996). Tourism, crime and international security issues. New York: Wiley.

Reisinger, Y. \& Mavondo, F. (2005). Travel Anxiety and Intentions to Travel Internationally: Implications of Travel Risk Perception. Journal of Travel Research, Vol. 48, pp. 212-225.

Sjöberg, L. (2002). Factors in risk perception. Risk Analysis, Vol. 20, No. 1, pp. 1-12.

Soderlund, M. (1998). Customer satisfaction and its consequences on customer behaviour revisited. The impact of different levels of satisfaction on word-of-mouth, feedback to the supplier and loyalty. International Journal of Service Industry Management, Vol. 9, No. 2, pp. 169-188.

Sönmez, S. \& Sirakaya, E. (2002). A distorted destination image? The case of Turkey. Journal of Travel Research, Vol. 41, No. 2, pp. 18 5-196.

Strydom, A. \& Nel, R. (2006). Evaluating Bloemfontein's image as a tourist destination. South African Journal of Economic and Management sciences. Vol. 9, No. 2, pp. 187-195.

Tam, J. L. M. (2000). The effects of service quality, perceived value and customer satisfaction on behavioral intentions. Journal of Hospitality and Leisure Marketing, Vol. 6, No. 4, pp. 31-43.

Tran, X.V. \& Bridges, F. S. (2009). Tourism and Crime in European Nations. e-Review of Tourism Research (eRTR), Vol. 7, No.3, pp. 52-67.

Wellington, H. N.A. (1998). Abrafo-Odumase: A case study of rural communities around Kakum conservation area. Kumasi: Department of Architecture and Planning, University of Science and Technology.

Yi, Y. (1990). A critical review of consumer satisfaction. In V. Zeithaml (Ed.), Review of marketing (pp. 68-123). Chicago, IL: American Marketing Association.

*** African Research Bulletin (2017). Egypt: Coptic Cathedral Attack, 17.1.2017, 21258.

*** BBC News, (2016). Egypt attack: Three tourists stabbed at Hurghada Hotel. BBC News. Available at: https://www.bbc.com/news/world-middle-east-35268713. Accessed on 3o December 2019.

*** BBC News, (2016). Burkina Faso attack: Al-Qaeda 'names' hotel attackers. BBC News. Available at: https: //www.bbc.com/news/world-africa-35342908. Accessed on 30 December 2019

*** Department of Geography and Regional Planning, GIS Remote Sensing and Cartography Unit, University of Cape Coast, Ghana (2019).

*** Ghana Tourism Authority (GTA), (2017).

*** GMMB-Ghana Museum and Monument Board Report, Cape Coast (2018). Annual Report, Accra: Ghana.

*** Institute of Statistical, Social and Economic Research (ISSER). The State of the Ghanaian Economy in 2016 (2017), University of Ghana, Legon, Ghana.

*** OSAC- Overseas Security Advisory Council (2019). Burkina Faso 2019 Crime and Safety Report. Available at: https://www.osac.gov/Content/Report/db697e4f-f3b9-41a3-9bdo-165806c8e4ao. Accessed on 3 January 2020.

**** World Travel and Tourism Council, WTTC (2016). Travel and Tourism Economic Impact 2016, Ghana.

Submitted:

24.10.2019
Revised:

19.02.2020
Accepted and published online

26.02.2020 